Historic, archived document

Do not assume content reflects current scientific knowledge, policies, or practices. 
. 


\section{che 3 \\ PRESERVATION OF DEAD LODGEPOLE PINE POSTS AND POLES}

\section{DAVID P. LOWERY AND JOHN R. HOST}
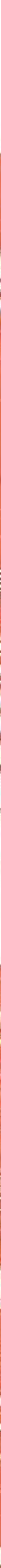



\title{
PRESERVATION OF DEAD LODGEPOLE PINE POSTS AND POLES
}

\author{
David P. Lowery and John R. Host
}

\author{
Intermountain Forest and Range Experiment Station \\ USDA Forest Service \\ Ogden, Utah 84401
}




\section{THE AUTHORS}

DAVID P. LOWERY is wood technologist, stationed at the Intermountain Station's Forestry Sciences Laboratory in Missoula, Montana.

JOHN R. HOST is a research forester also stationed at the Forestry Sciences Laboratory in Missoula.

\section{ACKNOWLEDGMENT}

The authors would like to express their appreciation to Harold and Louis Bouma of the Bouma Post Yards at Lincoln and Choteau, Montana, and Fred Behenna of the Kalispell Pole and Timber Company, Kalispell, Montana. The cooperation and helpful suggestions of these men during the course of the different investigations have been much appreciated. 


\section{RESEARCH SUMMARY}

Three studies on the processing and preservation of dead lodgepole pine posts and poles indicated that some care is necessary in selecting material to be treated with a preservative. Machinepeeled dead tree posts were somewhat rougher than peeled green tree posts and had a slight tendency to be stopped in the peeling machine. The steeping method of preservative treatment gave inconsistent retentions for the study times used, and none of these posts or poles met the retention specified. Poles treated by the hot and cold bath nonpressure method and posts treated by the pressure method had retentions exceeding the minimum specification requirements. The low moisture content of the dead posts and poles eliminated the necessity for air-drying them before treatment and reduced the time needed to get the minimum retention required. 


\section{CONTENTS}

$\underline{\text { Page }}$

INTRODUCTION . . . . . . . . . . . . . . . . I

PRESERVATIVE TREATMENT OF FENCEPOSTS BY THE COLD SOAK OR I

STEEPING METHOD . . . . . . . . . . . . . . . . .

Procedure . . . . . . . . . . . . . . . . 1

Results and Discussion ............. 2

PRESSURE TREATMENT OF DEAD LODGEPOLE PINE FENCEPOSTS . . . 6

Procedure . . . . . . . . . . . . . . 6

Results and Discussion . . . . . . . . . . 7

PRESERVATIVE TREATMENT OF POLES MADE FROM DEAD LODGEPOLE

PINE TREES . . . . . . . . . . . . . . . . 8

Procedure . . . . . . . . . . . . . . . 8

Results and Discussion .. . . . . . . . . 10

CONCLUSIONS . . . . . . . . . . . . . . 12

PUBLICATIONS CITED . . . . . . . . . . . . . 12

The use of trade, firm, or corporation names in this publication is for the information and convenience of the reader. Such use does not constitute an official endorsement or approval by the U.S. Department of Agriculture of any product or service to the exclusion of others which may be suitable. 


\section{INTRODUCTION}

The northern Rocky Mountain area has a tremendous number of dead lodgepole pine (Pinus contorta var. latifolia Dougl.) trees that have accumulated in the region's forests. Most of these trees were killed by the mountain pine beetle (Dendroctonus ponderosae Hopk.) during the past 25 years and, because of environmental conditions, a large proportion of the dead trees are still sound. A recent report (Lyon 1977) indicated that trees larger than 8 inches $(20.3 \mathrm{~cm})$ in diameter will stand indefinitely.

Because of their size, straightness, minimum taper, and ease of preservation, green lodgepole pine trees have been preferred in the northern Rocky Mountains for fenceposts, railings, corral poles, and utility poles. Tegethoff and others (1977) have determined that about 38 percent of the dead lodgepole pine trees in southeastern Idaho satisfy the specifications for power poles.

Use of dead trees for posts and poles has several distinct advantages: (1) the lower percent moisture content of the dead trees eliminates or reduces the relatively long air-seasoning time required for green wood products; (2) the lower moisture content also eliminates the necessity of acquiring and maintaining a large inventory, and reduces hauling costs to and from the treating plant; (3) the preservative penetrates and coats the wood surrounding various openings, thereby reducing the amount of untreated wood exposed to fungous attack; and (4) removal of these trees from the forest extends the timber supply, improves esthetics, and reduces fire hazard.

The objective of this investigation was to obtain information on the processing and preservation of posts and poles made from dead trees. Three studies, two of posts and one of poles, were made at separate commercial treating operations where different treating methods and schedules were used. The studies are discussed separately.

\section{PRESERVATIVE TREATMENT OF FENCEPOSTS BY THE COLD SOAK OR STEEPING METHOD}

\section{Procedure}

Seventy-five lodgepole pine fenceposts were cut from stems that had been piled for burning or from trees that had been felled in a precommercial thinning 4 years earlier. Most posts from the thinned trees had retained their bark, but many obtained from the slash piles were without bark. The posts were taken from a single area in western Montana.

In the field, posts were cut approximately 6.8 feet $(2.1 \mathrm{~m})$ long. In the laboratory, a 1 -inch $(2.5 \mathrm{~cm})$ disk was cut from each end of each post, and the posts were trimmed to the desired length, 6.5 feet $(2.0 \mathrm{~m})$. The disks, identified as to post, were used in the preparation of moisture content and specific gravity specimens. A strip, approximately 1 inch $(2.5 \mathrm{~cm})$ wide and containing the pith, was cut from the center portion of each disk. The strip was then sawed through the pith and specimens of sapwood and heartwood were cut from each strip's half. The specimens obtained from one half were used for specific gravity determinations, and those from the second half for moisture content determinations. Specific gravity was based on green volume and ovendry weight. The ovendry method was used to determine moisture content. 
Posts were separated into two groups, large and small, according to end diameter. Thirty-six of the posts were classified as small and 38 were classified as large. Diameters of each post were measured before and after debarking. The diameters of the small posts ranged from 2.6 to 3.4 inches $(6.6$ to $8.6 \mathrm{~cm}$ ) at the small end and from 3.1 to 4.3 inches $(7.9$ to $10.9 \mathrm{~cm})$ at the large end. The corresponding diameters for the large posts ranged from 3.9 to 5.2 inches $(9.9$ to $13.2 \mathrm{~cm}$ ) and from 4.4 to 5.7 inches $(11.2$ to $14.5 \mathrm{~cm})$.

At completion of laboratory testing, the posts were taken to a commercial treating plant where each post was debarked, capped, and pointed prior to treatment. At this time, two large posts were discarded, leaving 36 of each size post to be treated. Also, 13 air-seasoned posts from green trees were combined with the study posts for control purposes. The posts were then placed upright in a series of tanks filled to a depth of 30 inches $(76.2 \mathrm{~cm})$ with a 5 percent solution of pentachlorophenol in a light crude oil. Additional preservative was added during the 6-hour treatment to maintain the required depth. Three large posts, three small posts, and one control post, all selected at random, were removed from the tanks at 30-minute intervals. Two control posts were removed with the last group after 6 hours of steeping. The posts were then returned to the laboratory for examination.

A standard-size increment borer was used to extract a core from the approximate midpoint of the treated portion of each post. This boring was reserved for chemical analysis to determine the quantity of preservative absorbed. In addition, a disk was cut from near the midpoint of the treated area. The average sapwood depth and the average depth of penetration were determined from four measurements of each variable made on each disk. A chemical-indicating solution painted on the disk surface delineated the heartwood/sapwood boundary.

The borings were evaluated at a commercial testing laboratory. The three borings from the large or small posts treated for a specific length of time were combined for analytical purposes; so 24 determinations were made of the borings from the dead tree posts. The borings from the control posts, too, were combined as follows: (1) posts treated $0.5,1.0$, and 1.5 hours; (2) posts treated $2.0,2.5$, and 3.0 hours; (3) posts treated $3.5,4.0$, and 4.5 hours; (4) posts tréated 5.0 and 5.5 hours; and (5) borings from the two posts treated 6.0 hours.

\section{Results and Discussion}

The percent moisture content and specific gravity data for the small and large posts before treatment are summarized in tables 1 and 2 . For the small lodgepole pine posts the average moisture content of the heartwood was 15.8 percent and the range was from 14.2 to 18.1 percent. The average moisture content of the sapwood was 14.6 percent and the range from 12.3 to 18.3 percent. The average specific gravities of the heartwood and sapwood were similar 0.432 and 0.421 , respectively (table 1 ). These results indicate that the posts were sufficiently dry for preservative treatment and that no decay was present. The average specific gravity for lodgepole pine is 0.38 (U.S. Department of Agriculture 1974).

For the posts largest in diameter (table 2), the average moisture content of the heartwood was 23.0 percent and the range was from 18.8 to 27.5 percent. The moisture content of the sapwood averaged 19.8 percent and ranged from 16.5 to 23.8 percent. The average specific gravity of the heartwood was 0.430 and for the sapwood 0.419 . The percent moisture contents were slightly higher than those normally attained for air-seasoned posts prior to treatment and were higher than the moisture contents of the small posts. The specific gravity values were practically the same as those for the small diameter posts. 
Table 1.--Summaryl of average percent moisture content and specific gravity of test specimens taken from small lodgepole pine posts cut from dead trees before preservative treatment

\begin{tabular}{|c|c|c|c|c|}
\hline \multirow{2}{*}{$\begin{array}{l}\text { Length of } \\
\text { treatment }\end{array}$} & \multicolumn{2}{|c|}{ Average moisture content } & \multicolumn{2}{|c|}{ Average specific gravity } \\
\hline & Heartwood & Sapwood & Heartwood & Sapwood \\
\hline Hours & $----P \epsilon$ & $t---$ & & \\
\hline 0.5 & 18.1 & 14.3 & 0.439 & 0.404 \\
\hline 1.0 & 15.9 & 14.4 & .436 & .419 \\
\hline 1.5 & 15.9 & 14.3 & .459 & .463 \\
\hline 2.0 & 14.2 & 12.3 & .459 & .458 \\
\hline 2.5 & 14.3 & 12.7 & .412 & .413 \\
\hline 3.0 & 14.4 & 13.2 & .423 & .426 \\
\hline 3.5 & 16.5 & 16.7 & .438 & .449 \\
\hline 4.0 & 16.3 & 17.3 & .425 & .403 \\
\hline 4.5 & 16.1 & 18.3 & .438 & .424 \\
\hline 5.0 & 16.2 & 14.0 & .425 & .391 \\
\hline 5.5 & 15.1 & 13.9 & .391 & .429 \\
\hline 6.0 & 16.5 & 14.0 & .439 & .370 \\
\hline Average & 15.8 & 14.6 & 0.432 & 0.421 \\
\hline
\end{tabular}

${ }^{1}$ Each value is the average of six determinations.

Table 2.--Summaryl of average percent moisture content and specific gravity of test specimens taken from large lodgepole pine posts cut from dead trees before preservative treatment

\begin{tabular}{|c|c|c|c|c|}
\hline \multirow{2}{*}{$\begin{array}{l}\text { Length of } \\
\text { treatment }\end{array}$} & \multicolumn{2}{|c|}{ Average moisture content } & \multicolumn{2}{|c|}{ Average specific gravity } \\
\hline & Heartwood & Sapwood & Heartwood & Sapwood \\
\hline Hours & $---P$ & $E---$ & & \\
\hline 0.5 & 23.7 & 20.3 & 0.444 & 0.416 \\
\hline 1.0 & 21.9 & 19.4 & .443 & .472 \\
\hline 1.5 & 21.0 & 17.9 & .402 & .387 \\
\hline 2.0 & 26.4 & 21.1 & .440 & .461 \\
\hline 2.5 & 18.8 & 17.5 & .443 & .402 \\
\hline 3.0 & 23.8 & 21.7 & .412 & .396 \\
\hline 3.5 & 20.5 & 17.4 & .424 & .402 \\
\hline 4.0 & 24.9 & 23.8 & .433 & .424 \\
\hline 4.5 & 27.5 & 22.1 & .451 & .443 \\
\hline 5.0 & 23.3 & 18.5 & .431 & .400 \\
\hline 5.5 & 20.4 & 16.5 & .411 & .415 \\
\hline 6.0 & 23.5 & 21.8 & .432 & .405 \\
\hline Average & 23.0 & 19.8 & 0.430 & 0.419 \\
\hline
\end{tabular}

${ }^{1}$ Each value is the average of six determinations. 
A slight difficulty was noted in the peeling of bark from the dead tree posts. These posts often were stopped in the debarker, and if the stoppages were not corrected immediately an excessive amount of wood was removed. Also, the surface of the debarked dead tree posts was rougher than the surface of posts from green trees. Roughness was probably due to the lower moisture content at the time of debarking. Green tree posts are usually debarked within a week or so after arrival in the yard and before air seasoning. A few of the treated posts are shown in figure 1.

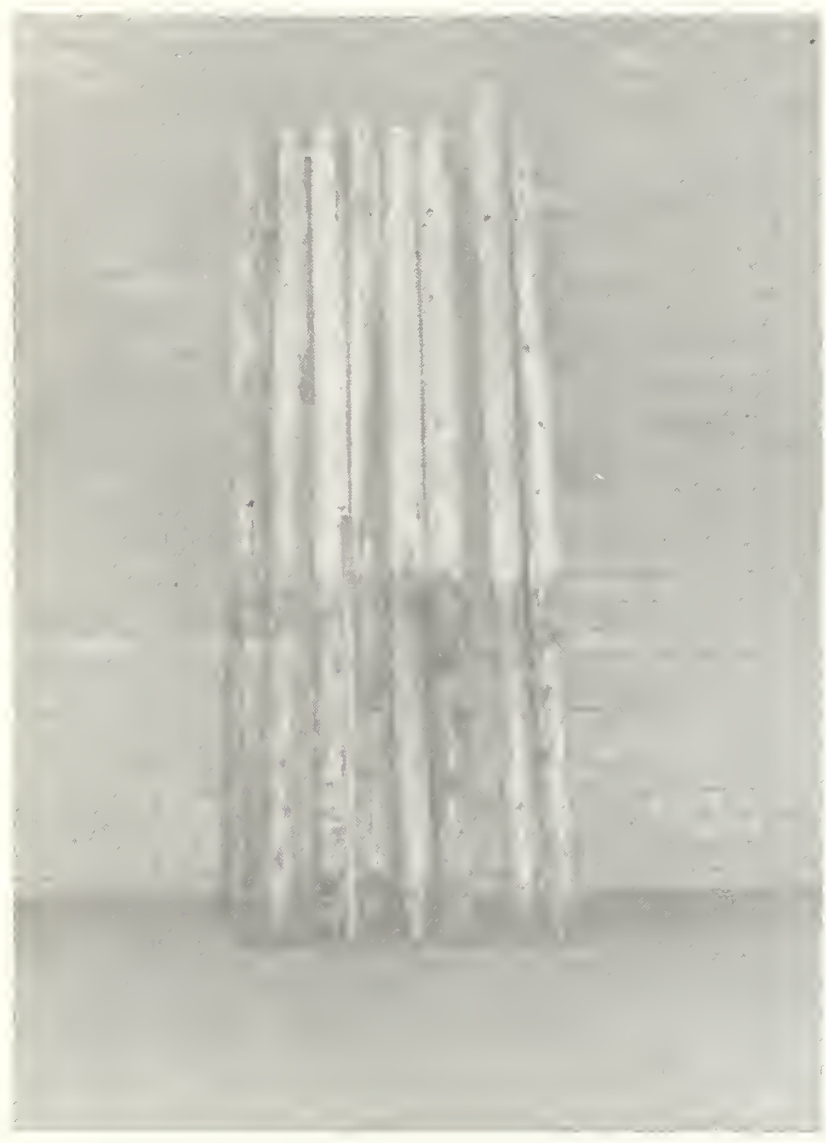

Figure 1.--A few of the lodgepole pine posts treated by the steeping method.

The disks taken from near the midpoint of the treated area were used to determine age, sapwood depth, and depth of preservative penetration. The average age of the small posts was 53 years and of the large posts, 67 years. The average sapwood depth was 0.47 inch $(1.2 \mathrm{~cm})$ and the average penetration, 0.46 inch $(1.2 \mathrm{~cm})$. These data indicate that the trees were relatively slow growing and that practically all the sapwood was penetrated by the preservative.

The borings were analyzed for preservative retention in accordance with American Wood Preservers' Association (AWPA) method A-5 (1969). The retention level specified for general-use fenceposts is $0.301 \mathrm{~b}$ per $\mathrm{ft}^{3}\left(4.81 \mathrm{~kg} / \mathrm{m}^{3}\right)$, but the results of our analysis indicated that none of the treatments gave this minimum retention. The range of retentions was from 0.00 to $0.28 \mathrm{lb}$ per $\mathrm{ft}^{3}\left(0.00\right.$ to $4.49 \mathrm{~kg} / \mathrm{m}^{3}$ ) (tables 3 and 4 ). There was no consistent relation between the length of treating time, the depth of preservative penetration, and the pounds per cubic foot preservative retention. Neither was there a consistent difference between the large and small posts. The results from the control posts were also inconsistent. The average retention for these posts was $0.035 \mathrm{lb}$ per $\mathrm{ft}^{3}\left(0.56 \mathrm{~kg} / \mathrm{m}^{3}\right)$ and the range was from 0.02 to $0.05 \mathrm{lb}$ per $\mathrm{ft}^{3}\left(0.32\right.$ to $\left.0.80 \mathrm{~kg} / \mathrm{m}^{3}\right)$.

The usual treating cycle for green tree posts is 24 hours. Obviously, our studytreating times were much too short to obtain adequate retèntion. Additional work needs to be done to determine the optimum treating cycle for dead tree posts by the steeping method. 
Table 3.--Summary of results taken from small fenceposts cut from dead lodgepole pine trees treated by the steeping method

\begin{tabular}{|c|c|c|c|c|c|c|c|}
\hline \multirow[t]{2}{*}{ Post numbers } & \multirow{2}{*}{$\begin{array}{l}\text { Length of } \\
\text { treatment } \\
\text { Hours }\end{array}$} & \multicolumn{2}{|c|}{$\begin{array}{c}\text { Average } \\
\text { sapwood depth }\end{array}$} & \multicolumn{2}{|c|}{$\begin{array}{l}\text { Average depth } \\
\text { of penetration }\end{array}$} & \multicolumn{2}{|c|}{$\begin{array}{l}\text { Average } \\
\text { retention }\end{array}$} \\
\hline & & Inches & $\mathrm{cm}$ & Inches & $\mathrm{cm}$ & $L b / f t^{3}$ & $\mathrm{~kg} / \mathrm{m}^{3}$ \\
\hline $8,31,32$ & 0.5 & 0.46 & 1.17 & 0.37 & 0.94 & 0.05 & 0.80 \\
\hline $9,16,28$ & 1.0 & .48 & 1.22 & .49 & 1.24 & .14 & 2.24 \\
\hline $17,36,37$ & 1.5 & .39 & .99 & .33 & .84 & .00 & .00 \\
\hline $23,30,40$ & 2.0 & .36 & .91 & .35 & .90 & .06 & .96 \\
\hline $14,22,24$ & 2.5 & .69 & 1.75 & .58 & 1.47 & .10 & 1.60 \\
\hline $10,35,39$ & 3.0 & .49 & 1.24 & .51 & 1.30 & .12 & 1.92 \\
\hline $7,11,20$ & 3.5 & .55 & 1.40 & .58 & 1.47 & .28 & 4.49 \\
\hline $25,26,34$ & 4.0 & .51 & 1.30 & .55 & 1.40 & .05 & .80 \\
\hline $5,15,21$ & 4.5 & .62 & 1.57 & .54 & 1.37 & .18 & 2.88 \\
\hline $6,13,19$ & 5.0 & .53 & 1.35 & .64 & 1.63 & .10 & 1.60 \\
\hline $1,27,43$ & 5.5 & .45 & 1.14 & .33 & .84 & .27 & 4.32 \\
\hline $2,33,42$ & 6.0 & .42 & 1.07 & .37 & .94 & .01 & .16 \\
\hline Average & & 0.50 & 1.27 & 0.47 & 1.19 & 0.11 & 1.76 \\
\hline
\end{tabular}

Table 4.--Summary of results taken from large fenceposts cut from dead lodgepole pine trees treated by the steeping method

\begin{tabular}{|c|c|c|c|c|c|c|c|}
\hline \multirow[t]{2}{*}{ Post numbers } & \multirow{2}{*}{$\begin{array}{l}\text { Length of } \\
\text { treatment } \\
\text { Hours }\end{array}$} & \multicolumn{2}{|c|}{$\begin{array}{c}\text { Average } \\
\text { sapwood depth }\end{array}$} & \multicolumn{2}{|c|}{$\begin{array}{l}\text { Average depth } \\
\text { of penetration }\end{array}$} & \multicolumn{2}{|c|}{$\begin{array}{l}\text { Average } \\
\text { retention }\end{array}$} \\
\hline & & Inches & $\mathrm{cm}$ & Inches & $c m$ & $L b / f t^{3}$ & $\mathrm{~kg} / \mathrm{m}^{3}$ \\
\hline $31,33,39$ & 0.5 & 0.49 & 1.24 & 0.34 & 0.86 & 0.21 & 3.36 \\
\hline $1,4,24$ & 1.0 & .43 & 1.09 & .33 & .84 & .12 & 1.92 \\
\hline $11,28,37$ & 1.5 & .43 & 1.09 & .48 & 1.22 & .13 & 2.08 \\
\hline 2,$17 ; 25$ & 2.0 & .39 & .99 & .36 & .91 & .06 & .96 \\
\hline $15,18,34$ & 2.5 & .36 & .91 & .35 & .89 & .08 & 1.28 \\
\hline $9,22,38$ & 3.0 & .58 & 1.47 & .65 & 1.65 & .18 & 2.88 \\
\hline $10,13,36$ & 3.5 & .58 & 1.47 & .47 & 1.19 & .27 & 4.32 \\
\hline $8,20,35$ & 4.0 & .32 & .81 & .34 & .86 & .07 & 1.12 \\
\hline $21,30,32$ & 4.5 & .46 & 1.17 & .55 & 1.40 & .08 & 1.28 \\
\hline $5,6,16$ & 5.0 & .49 & 1.24 & .57 & 1.45 & .14 & 2.24 \\
\hline $7,19,23$ & 5.5 & .39 & .99 & .43 & 1.09 & .10 & 1.60 \\
\hline $3,12,26,27,29$ & 6.0 & .40 & 1.02 & .46 & 1.17 & .08 & 1.28 \\
\hline Average & & 0.44 & 1.12 & 0.44 & 1.12 & 0.13 & 2.08 \\
\hline
\end{tabular}




\section{PRESSURE TREATMENT OF DEAD LODGEPOLE PINE FENCEPOSTS}

\section{Procedure}

Thirty-nine posts from dead lodgepole pine trees were taken from a single national forest in western Montana for use in this study. The same general procedure was followed in preparing the posts for treatment as in the preceding study. Disks were cut from both ends of each post and heartwood and sapwood specimens were cut from the disks for determination of specific gravity and percent moisture content. The posts were also cut to a uniform length, $6.5 \mathrm{ft}(2.0 \mathrm{~m})$.

The posts were next carried to a commercial wood-treating plant and all but five of the posts were debarked. The posts were then weighed to the nearest $0.51 \mathrm{~b}(0.23$ $\mathrm{kg}$ ). The post number, weight, and end diameter were marked on metal tags and fastened to the respective post. Trams were used to transport the posts into the treating cylinder and the study posts were loaded on the last tram to enter the cylinder (fig. 2).

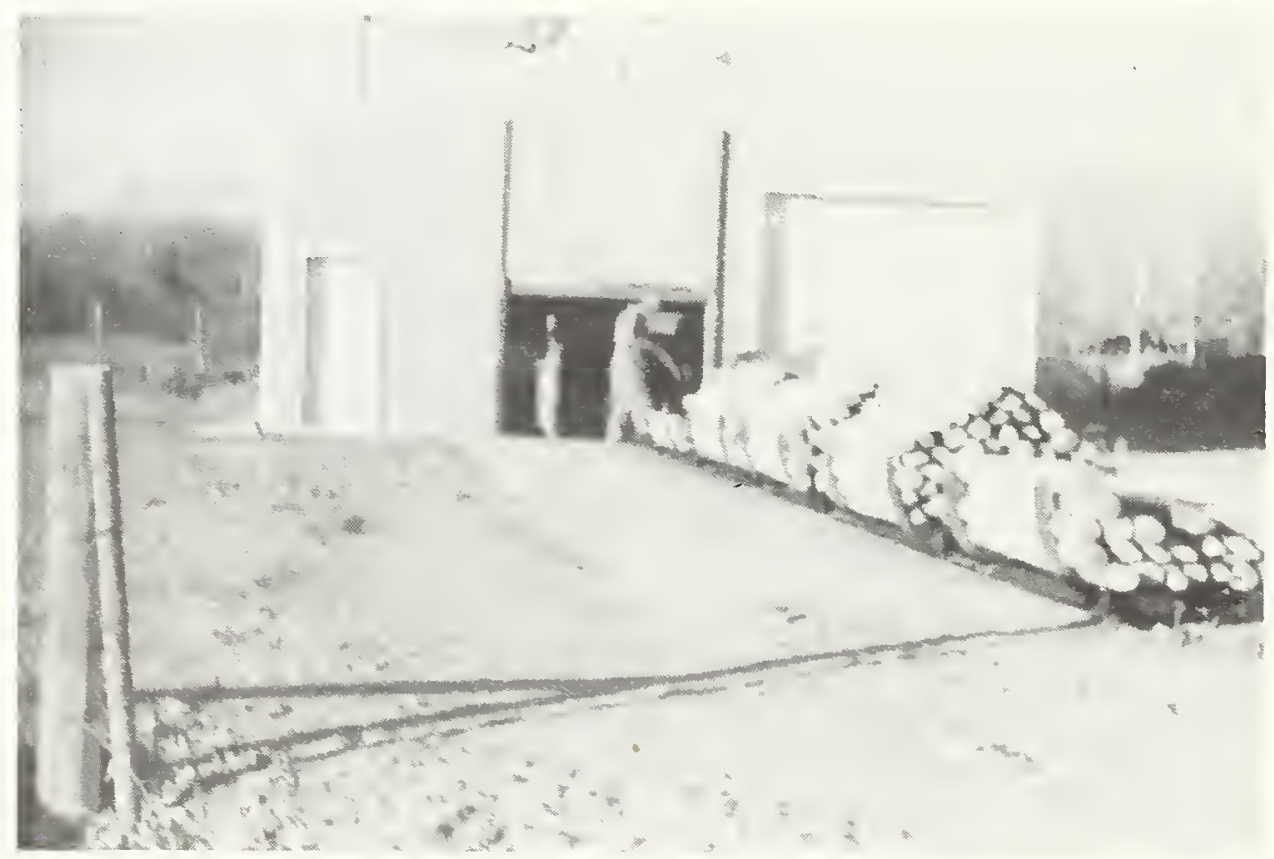

Figure 2.--Lodgepole pine study posts being loaded on last charge tram car prior to treatment by the pressure method.

After the cylinder is loaded and sealed, the usual treating procedure is to draw and maintain an initial vacuum of about 27 inches of mercury $(9.83 \mathrm{kPa})$ for 30 minutes. At the completion of this interval, without releasing the vacuum, the cylinder is filled with the preservative solution and a pressure of $100 \mathrm{lb}$ per inch ${ }^{2}(689.48$ $\mathrm{kPa}$ ) is applied for 3 hours. The cylinder is then drained, the tram cars removed, and the posts unloaded and bulk piled until sold.

The preservative used is an unheated water solution, 1.50 to 1.75 percent of fluorchrome arsenate phenol, type B (Osmosalts). Sodium fluoride, sodium arsenate, sodium dichromate, and dinitrophenol are the principal preservative compounds. 
The normal procedure was followed in treating the study posts except that the pressure period was reduced to 15, 30, or 45 minutes. After the pressure had been applied for 15 minutes, the cylinder was drained and opened, and 11 posts, including one with bark, were removed. After a second 15-minute pressure period another group of 12 posts, including one with bark, were removed; and after a third 15-minute pressure period, the remaining 15 posts, including three with bark, were removed. Upon removal, the posts were immediately reweighed to the nearest $0.51 \mathrm{~b}(0.23 \mathrm{~kg})$ and the end diameter was remeasured.

In the 1 aboratory, a disk was cut from the approximate center of each post, and the age, sapwood depth, and preservative penetration were noted. The disks were then individually placed in polyethylene bags and shipped to the preservative manufacturer for chemical analysis. Increment borings, too, were taken from the post and sent for analysis.

\section{Results and Discussion}

Percent moisture content of the specimens taken prior to treatment ranged from 9.1 to 24.6 percent and moisture content averaged 13.2 percent. The specific gravity of the specimens ranged from 0.294 to 0.493 and averaged $0.378--a b o u t$ the same as the published value of 0.38 (U.S. Department of Agriculture 1974). The percent moisture content and specific gravity data are summarized by treatment in table 5 .

Table 5.--Before treatment summary of average percent moisture content and specific gravity of test specimens taken from fenceposts cut from dead lodgepole pine trees and treated with preservatives by three different pressure treating schedules

Average

\begin{tabular}{|c|c|c|c|}
\hline & & & Average \\
\hline & Number of & Average moisture content & specific gravity \\
\hline Treating schedule & posts & Heartwood & Heartwood \\
\hline
\end{tabular}

30 min vacuum and 15 min pressure, 100 psi

$30 \mathrm{~min}$ vacuum and $30 \mathrm{~min}$ pressure, $100 \mathrm{psi}$

$30 \mathrm{~min}$ vacuum and $45 \mathrm{~min}$

pressure, 100 psi 16

11

12

Overa11 average
1

2

12.1

0.377

0.371

12.3

11.6

.404

.368

14.1

13.3

15.8

.391

.363

0.362

Again, debarking the dead tree posts demanded special attention to prevent excessive wood loss. Deep checks on the post surface caused the floating rosser head to stop the post and gouge the surface. Also, as before, the post surface was somewhat rougher than that of newly peeled green posts. A few of the study posts were of such low quality and appearance that under ordinary circumstances they would have been discarded.

The ages of the posts varied from 17 to 55 years. The sapwood depth ranged from 0.38 inch to 2.00 inches $(1.0$ to $5.1 \mathrm{~cm})$. Preservative penetration measurements were made on the borings using Chrome Azurol $\mathrm{S}$ as a copper detecting reagent (AWPA Method A-3, 1969) and a mixture of 0-anisidine hydrochloride and sodium nitrate as a pine heartwood indicator (AWPA M-2, 1969). The borings all showed 100 percent penetration of the sapwood. The post-treatment data are summarized in table 6. 
Table 6.--Summary of results obtained from fenceposts cut from dead lodgepole pine trees and treated with preservatives by three different pressure testing schedules

\begin{tabular}{|c|c|c|c|c|c|c|c|}
\hline \multirow[t]{2}{*}{ Treating schedule } & \multirow[t]{2}{*}{$\begin{array}{l}\text { Number of } \\
\text { posts }\end{array}$} & \multicolumn{2}{|c|}{$\begin{array}{l}\text { Average depth } \\
\text { of sapwood }\end{array}$} & \multicolumn{2}{|c|}{$\begin{array}{l}\text { Average depth } \\
\text { of penetration }\end{array}$} & \multicolumn{2}{|c|}{$\begin{array}{l}\text { Average } \\
\text { preservative } \\
\text { retention }\end{array}$} \\
\hline & & Inches & $\mathrm{cm}$ & Inches & $\mathrm{cm}$ & $L b / f t^{3}$ & $\mathrm{~kg} / \mathrm{m}^{3}$ \\
\hline $\begin{array}{l}30 \text { min vacuum and } 15 \mathrm{~min} \\
\text { pressure, } 100 \mathrm{psi} \\
30 \mathrm{~min} \text { vacuum and } 30 \mathrm{~min}\end{array}$ & 11 & 0.85 & 2.16 & 0.84 & 2.13 & 0.517 & 8.28 \\
\hline $\begin{array}{l}\text { pressure, } 100 \mathrm{psi} \\
30 \mathrm{~min} \text { vacuum and } 45 \mathrm{~min}\end{array}$ & 12 & .89 & 2.26 & .89 & 2.26 & .576 & 9.23 \\
\hline pressure, 100 psi & 16 & .88 & 2.24 & .86 & 2.18 & .701 & 11.23 \\
\hline Average & & 0.87 & 2.21 & 0.86 & 2.18 & 0.611 & 9.79 \\
\hline
\end{tabular}

Preservative retention assays were performed on samples cut from the disks for each of the three treated groups. Individual samples were combined for each group and the group sample was assayed for copper, chromium, and arsenic by AWPA Method A-9 (Xray emission spectroscopy). Al1 samples exceeded the minimum retention of $0.41 \mathrm{~b}$ per $\mathrm{ft}^{3}\left(6.41 \mathrm{~kg} / \mathrm{m}^{3}\right)$ of copper, chrome, and arsenic as required by AWPA C-5 for lodgepole pine fenceposts.

\section{PRESERVATIVE TREATMENT OF POLES MADE FROM DEAD LODGEPOLE PINE TREES}

\section{Procedure}

Thirty logs from dead lodgepole pine trees were selected in a sawmill storage yard for use in this investigation. The 1 ogs, 20,25 , or $30 \mathrm{ft} 1$ ong $(6.1,7.6$, or $9.1 \mathrm{~m}$ ) were suitable for poles in classes 5,6 , or 7 . Ten of the poles were $20 \mathrm{ft}$ long $(6.1 \mathrm{~m}), 18$ were $25 \mathrm{ft}$ long $(7.6 \mathrm{~m})$, and 2 were $30 \mathrm{ft}$ long $(9.1 \mathrm{~m})$. After selection, the poles were delivered to a commercial pole treating plant for processing and treatment.

Although the poles had very little bark, they were machine-peeled, numbered, and stored until time for treatment. During storage, the circumference at the top, butt, and groundline of each pole was measured and recorded and, in addition, a 1- or 2-inch $(2.5-$ or $5.1-\mathrm{cm})$ thick disk was cut from both ends of the poles (fig. 3). These disks, numbered as to pole of origin, were used in the preparation of percent moisture content and specific gravity test specimens in the same manner described earlier for the fencepost disks. 


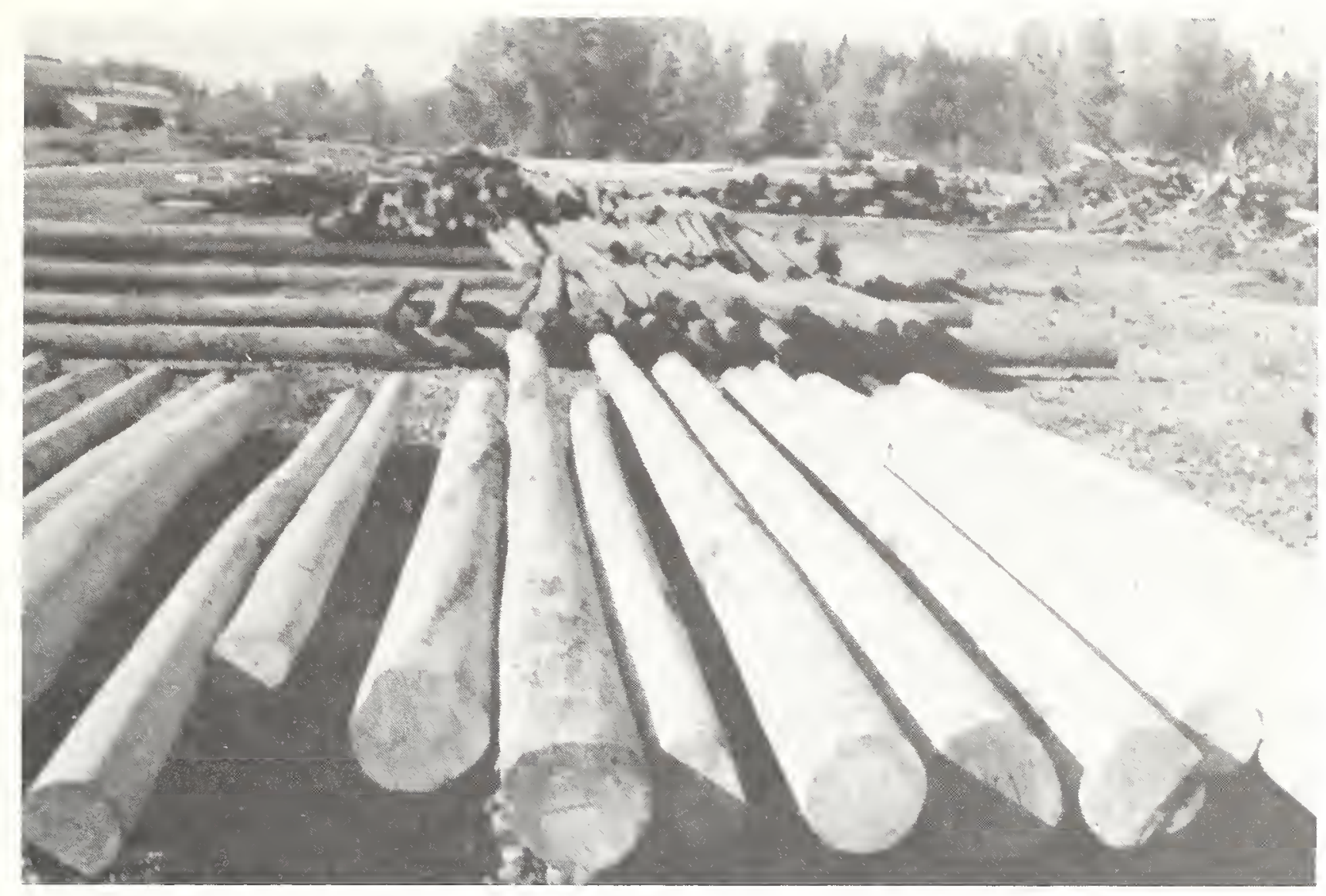

Figure 3.--A few poles spread for examination and end sampling prior to treatment by the hot and cold bath method.

The poles were then randomly separated into two groups, based on length, and the poles in each group were randomly assigned a specific treatment. The six treating schedules and the number of poles from each group treated by the different schedules were as follows:

$$
\frac{\text { Time }}{\text { Hours }}
$$

Poles used

1. 'Six-hour hot bath followed by 12-hour cold bath.

2. Four-hour hot bath followed by 6-hour cold bath.

3. Two-hour hot bath followed by 6-hour cold bath.

4. Nine-hour cold soak.

5. Six-hour cold soak.

6. Four-hour cold soak. 
The commercial procedure presently used consists of placing the poles upright in a treating tank filled to a depth of approximately $9 \mathrm{ft}(2.7 \mathrm{~m})$ with a preservative solution of about 5.1 percent pentachlorophenol in a heavy oil carrier. The preservative solution is then heated to a minimum of $190^{\circ} \mathrm{F}\left(88^{\circ} \mathrm{C}\right)$ and this temperature is maintained for 6 hours. At the completion of this interval, the hot solution is replaced with preservative solution of the same concentration, at ambient temperature. The poles remain in this bath for an additional 6 hours, after which the tank is drained and the poles removed. Additional preservative solution is periodically added during the treatment to maintain the desired solution depth.

After the study poles had been treated, they were returned to the storage area and sampled. Sampling consisted of cutting a section, approximately 10 inches $(25.4 \mathrm{~cm})$ from the center of the treated length. These sections, identified as to pole, were used to determine the depth of sapwood, the depth of preservative penetration, and the preservative retention in pounds per cubic foot. A commercial testing laboratory made the post-treatment evaluations in accordance with procedures recommended by AiPA (1969).

\section{Results and Discussion}

The percent moisture content and specific gravity determinations are summarized in table 7. These data show that the average values are fairly consistent. The overall average percent moisture contents for the heartwood and sapwood were 19.5 and 20.6, respectively, and the overall average specific gravity for the heartwood was 0.396 and for the sapwood, 0.399. The percent moisture content individual values ranged from 12.9 to 27.8 and individual specific gravity values ranged from 0.335 to 0.451 .

Table 7.--Before treatment summary of average percent moisture content and specific gravity determinations made on test specimens taken from dead lodgepole pine poles

Average

Number Average moisture content specific gravity

Treatment schedule of poles Heartwood Sapwood

Heartwood Softwood

- - - Percent - - -

6-hour hot and 12-hour cold bath

4-hour hot and 6-hour cold bath

2-hour hot and 6-hour cold bath

9-hour cold soak

6-hour cold soak

4-hour cold soak

Average
6

6

6

4

4

4
17.7

19.3

19.4

21.1

18.9

22.0

19.5
17.4

20.5

19.9

23.9

21.3

22.3
0.405

.398

400

.397

.390

.400 .414

.377 .390

.390 .402

0.399

0.396

0.399 
In contrast to peeling the fenceposts, no difficulty was encountered in debarking the poles. Apparently, the greater diameter, size, and weight of the poles or the different capacity of the machine prevented stoppages in the peeling operation. In general, the appearance of the peeled poles was satisfactory although the surface was again slightly rougher than that of freshly peeled green poles. All of the poles had surface checks of varying lengths and widths. The checks on 10 of the poles were greater than 0.25 inch $(0.6 \mathrm{~cm})$ wide. In addition, four of the poles had wormholes 0.125 inch $(0.3 \mathrm{~cm})$ or greater in diameter. Occurrence of these defects points out the need for greater care when selecting poles from dead trees.

The results of the post-treatment evaluations are summarized in table 8. The average depth of the sapwood for all poles was 1.5 inches $(3.7 \mathrm{~cm})$ and the range was from 0.50 inch to 2.90 inches $(1.3$ to $7.4 \mathrm{~cm})$.

Preservative penetration was determined by using the benzedine dihydrochloride stain method of AWPA Standard M-2 (1969). Specifications for poles treated by the hot and cold bath method require that the preservative penetrate a minimum of 0.75 inch $(1.9 \mathrm{~cm})$ and 85 percent of the sapwood. The average depth of preservative penetration was 1.41 inches $(3.6 \mathrm{~cm})$ and the range was from 0.63 inch to 2.25 inches $(1.6$ to 5.7 $\mathrm{cm})$. Only one of the poles had less than the minimum required penetration and, except for those poles given a 4-hour cold soak, all the poles met the 85 percent penetration of the sapwood requirement.

The preservative retention was determined using the method described in AWPA Standard A-5 (1969). The preservative retention requirement of the specification stipulates that a minimum of $1 \mathrm{lb}(0.45 \mathrm{~kg})$ of dry pentachlorophenol shall be in the outer 0.50 inch $(1.3 \mathrm{~cm})$. All the study poles treated by the hot and cold bath method exceeded this requirement and none of the poles treated by the cold soak method attained this retention. The average retention for those poles treated by the hot and cold bath method was $1.64 \mathrm{lb}$ per $\mathrm{ft}^{3}\left(26.27 \mathrm{~kg} / \mathrm{m}^{3}\right)$ and the range was from 1.08 to $2.00 \mathrm{lb}$ per $\mathrm{ft}^{3}\left(17.30\right.$ to $\left.32.04 \mathrm{~kg} / \mathrm{m}^{3}\right)$. The average retention for those poles treated by the soaking method was $0.36 \mathrm{lb}$ per $\mathrm{ft}^{3}\left(5.77 \mathrm{~kg} / \mathrm{m}^{3}\right)$ and the range was from 0.16 to $0.741 \mathrm{~b}$ per $\mathrm{ft}^{3}\left(2.56\right.$ to $\left.11.85 \mathrm{~kg} / \mathrm{m}^{3}\right)$. The average retention for all the study posts was $1.131 \mathrm{~b}$ per $\mathrm{ft}^{3}\left(18.10 \mathrm{~kg} / \mathrm{m}^{3}\right)$.

A statistical analysis of the post-treatment data indicated the only significant difference in the preservative retention was due to treating method (table 8).

Table 8.--Summary of results obtained from poles cut from dead lodgepole pine trees and treated with preservative by different schedules and either the hot and cold bath or steeping method

\begin{tabular}{|c|c|c|c|c|c|c|c|}
\hline \multirow[t]{2}{*}{ Treating schedule } & \multirow[t]{2}{*}{$\begin{array}{l}\text { Number } \\
\text { of } \\
\text { poles }\end{array}$} & \multicolumn{2}{|c|}{$\begin{array}{l}\text { Average } \\
\text { sapwood } \\
\text { depth }\end{array}$} & \multicolumn{2}{|c|}{$\begin{array}{l}\text { Average depth } \\
\text { of } \\
\text { penetration }\end{array}$} & \multicolumn{2}{|c|}{$\begin{array}{l}\text { Average } \\
\text { preservative } \\
\text { retention }\end{array}$} \\
\hline & & Inches & $\mathrm{cm}$ & Inches & $\mathrm{cm}$ & $L b / f t^{3}$ & $\mathrm{~kg} / \mathrm{m}^{3}$ \\
\hline $\begin{array}{l}\text { 6-hour hot and 12-hour } \\
\text { cold bath }\end{array}$ & 6 & 1.46 & 3.71 & 1.48 & 3.76 & 1.77 & 28.36 \\
\hline $\begin{array}{l}\text { 4-hour hot and 6-hour } \\
\text { cold bath }\end{array}$ & 6 & 1.53 & 3.89 & 1.69 & 4.29 & 1.54 & 24.67 \\
\hline $\begin{array}{l}\text { 2-hour hot and 6-hour } \\
\text { cold bath }\end{array}$ & 6 & 1.39 & 3.53 & 1.38 & 3.51 & 1.61 & 25.79 \\
\hline 9-hour cold soak & 4 & 1.36 & 3.45 & 1.31 & 3.33 & .36 & 5.77 \\
\hline 6-hour cold soak & 4 & 1.14 & 2.90 & 1.16 & 2.95 & .32 & 5.13 \\
\hline 4-hour cold soak & 4 & 1.96 & 4.98 & 1.25 & 3.18 & .39 & 6.25 \\
\hline Average & & 1.47 & 3.73 & 1.41 & 3.58 & 1.13 & 18.10 \\
\hline
\end{tabular}


The results of the three preservative treatment investigations indicate that some care should be exercised in selecting posts and poles from dead trees. The frequent occurrence of long, deep checks and wormholes results in lower quality and a higher cul1 factor in the dead tree products. In addition, greater care is required in processing the dead tree posts and poles. Posts exhibited a tendency to get stopped in the debarker and to be stripped of an excessive amount of wood, especially as the debarker head was passing over a deep or irregular check on the surface. This problem was not encountered in debarking the poles.

The, debarked posts and poles were somewhat rougher on the surface than newly peeled green tree posts and poles. This undoubtedly was due to the lower percent moisture content of the dead tree products. More frequent maintenance of the debarking head may aid in alleviating this problem.

The steeping method of preservative treatment gave inconsistent preservative retentions for the treating times used. None of the 85 posts treated by this method met the retention specification of $0.30 \mathrm{lb}$ per $\mathrm{ft}^{3}\left(4.81 \mathrm{~kg} / \mathrm{m}^{3}\right)$. The retentions of the study posts ranged from 0.00 to $0.28 \mathrm{lb}$ per $\mathrm{ft}^{3}\left(0.00\right.$ to $\left.4.49 \mathrm{~kg} / \mathrm{m}^{3}\right)$. Although the greatest steeping time used was 6 hours, more time than that is needed. There are indications that the time required to treat dead tree posts would be less than the 24 hours needed to treat green tree posts.

Pressure treatment of dead lodgepole pine posts gave directly opposite results. All study posts, including those with bark met the preservative retention specification of $0.40 \mathrm{lb}$ per $\mathrm{ft}^{3}\left(6.41 \mathrm{~kg} / \mathrm{m}^{3}\right)$. A treating cycle of 30 minutes vacuum and 15 minutes of pressure at $100 \mathrm{ib}$ per inch ${ }^{2}(689.48 \mathrm{kPa})$, the minimum treating time used, was more than adequate to obtain the necessary retention. The pressure treating time can thus be reduced to about one-twelfth the time needed to treat green posts.

Of the two treating methods used with poles from dead lodgepole pine trees, the results indicate that the hot and cold bath is the better method. All the poles treated by this method exceeded the specification requirements for preservative penetration and retention, 0.75 inch $(1.9 \mathrm{~cm})$ or 85 percent of the sapwood and 1 lb $(0.45 \mathrm{~kg})$ of dry pentachlorophenol in the outer 0.5 inch $(1.3 \mathrm{~cm})$, respectively. None of the poles treated by the cold soak method met the preservative retention requirement and only the poles soaked for 9 and 6 hours met the preservative penetration requirement.

\section{PUBLICATIONS CITED}

American Wood Preservers' Association.

1969. AWPA standards (loose leaf and currently revised). Am. Wood Preserv. Assoc., Washington, D.C.

Lyon, L. J.

1977. Attrition of lodgepole pine snags on the Sleeping Child burn, Montana. USDA For. Serv. Res. Note INT-219, 4 p. Intermt. For. and Range Exp. Stn., Ogden, Utah.

Tegethoff, A. C., T. E. Hinds, and W. E. Eslyn.

1977. Beetle-killed lodgepole pines are suitable for powerpoles. For. Prod. J. $27(9): 21-23$.

U.S. Department of Agriculture.

1974. Wood handbook - wood as an engineering material. USDA For. Serv. Wood Handb.

72. Washington, D.C. 
Lowery, David P., and John R. Host.

1979. Preservation of dead lodgepole pine posts and poles. USDA

For. Serv. Res. Pap. INT-241, 12 p. Intermt. For. and Range

Exp. Stn., Ogden, Utah.

Three studies were made using posts and poles cut from dead lodgepole pine trees. Steeping was an unsatisfactory method for treating fenceposts, but poles treated by the hot and cold bath nonpressure method and posts treated by the pressure method had retentions exceeding the minimum specification requirements.

KEYWORDS: Preservation, dead tree utilization, lodgepole pine, posts and poles, treating methods

Lowery, David P., and John R. Host.

1979. Preservation of dead lodgepole pine posts and poles. USDA

For. Serv. Res. Pap. INT-241, 12 p. Intermt. For. and Range

Exp. Stn., Ogden, Utah.

Three studies were made using posts and poles cut from dead lodgepole pine trees. Steeping was an unsatisfactory method for treating fenceposts, but poles treated by the hot and cold bath nonpressure method and posts treated by the pressure method had retentions exceeding the minimum specification requirements.

KEYWORDS: Preservation, dead tree utilization, lodgepole pine, posts and poles, treating methods 
The Intermountain Station, headquartered in Ogden, Utah, is one of eight regional experiment stations charged with providing scientific knowledge to help resource managers meet human needs and protect forest and range ecosystems.

The Intermountain Station includes the States of Montana, Idaho, Utah, Nevada, and western Wyoming. About 250 million acres, or 90 percent, of the land area in the Station territory are classified as forest and rangeland. These lands include grasslands, deserts, shrublands, alpine areas, and well-stocked forests. They supply fiber for forest industries; minerals for energy and industrial development; and water for domestic and industrial consumption. They also provide recreation opportunities for millions of visitors each year.

Field programs and research work units of the Station are maintained in:

Boise, Idaho

Bozeman, Montana (in cooperation with Montana State University)

Logan, Utah (in cooperation with Utah State University)

Missoula, Montana (in cooperation with the University of Montana)

Moscow, Idaho (in cooperation with the University of Idaho)

Provo, Utah (in cooperation with Brigham Young University

Reno, Nevada (in cooperation with the University of Nevada)

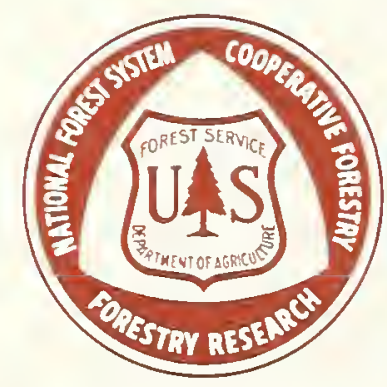

FOREST RESIJUES UTILIZATION RESEARCH ANO OEVELOPMENT PROGRAM 